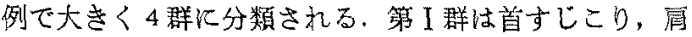
こりならびにその随伴症状に対する效果を期街した症例

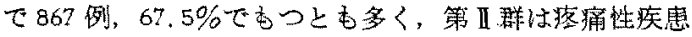
の鎮痛効果 338 例， $26.3 \%$ ，第群は機能障害に対する 機能回復促進効果 72 例, $5.6 \%$ ，第 $\mathrm{N}$ 群は針麻酔効果 8 例, $0.6 \%$ てあった。

次に各群の内容をみると，第 I 群では首すじこり，层 こりばかりでなく，これ《随伴する緊張性頭痛, 喕重感, 非炎症性耳痛, 㣪垩神経痛, 不定型顔面痛, 顽部痛など の頭钼部顔面の疼痛やこれに類する不快感，さらに頸性 めま，頛性耳鳴，非耳疾性の耳閔感，咽喉頭異常感など の愁訴に対して频項筋の過緊張を縵和することれより， 諸愁訴を除去する．有効な場合はほとえど数回以内の治 療で愁訴方除去されるが，施行してみて宗つたく效果の ないときや除去した愁訴加すぐ再発し，数回以上くり加 えしてをまったく同じ場合は重大な器睤障㕩があること が考光られ，その检索が必要となる。去た仮面うつ病や 神経症あるい怯心因性要素の强い場合は効果がない。

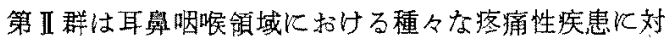
して鎮痛効果が期待される群である。外耳炎, 扁桃炎,

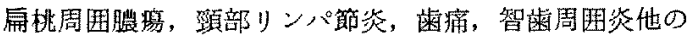
急性炎症に伴万疼痛あるいは急性副覓整炎，術後性煩部 のろ腫なとにに伴ら三叉神経痛などのありられた疼痛に対 して即効的に效果が得られる。

また征来の方法ては治療効果があがりにくい顎関節 症, Hilger 症候群のような粘膜病变を伴わない㬋頍部

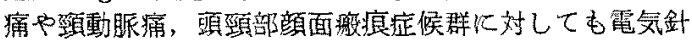
治瘞は著效す万，真性三叉神経痛ではブロック点飞電気 針治潦を施行するが，時化 Neuralgie を誘発することも ある.

ベーチェット病にともなう難治性再発性了フタ行沿し ても局所に針を刺入し，通電することに上り疼痛を除去 し，アフタの治㿁を促進させることができる。

癌性疼痛に対しても，比較的限局している場合は鎮痛 鼡の量を減量させる意味で試みてよいと考える。

第群は機能障害に対する機能回復促進効果である. 例えば末梢性顔面神経腺痻に対しては理学療法の一手段 として有意穿である，顔面疼整に対して屯顔面神経ブロ ックし同程度の効果が得られる。メ二エール病，良性発

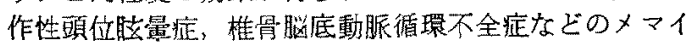

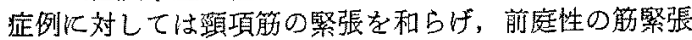
のアンバランスを調整すること化より，古る程度メマイ 発作をコントロールすることができる．しかしこの群に 対する雪気針治療治療体系からみれば，あくまでも補
助的手段化すきない。

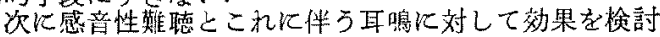
した。症例はいずれも成人て，突発難㯖後䕗症 4 例，老 人性難聴 6 例，騷音性嚾聴 2 例，パニマイシン中毒，雨 側メ二エール病, 䫓部外第捘连症各 1 例の悖力が固定し ていると考えられ，Jerger II 型を示した15例 25 耳孝

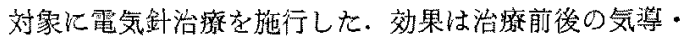
骨尊聴力検植，語音聴力检查ならびに耳鳴検查により判

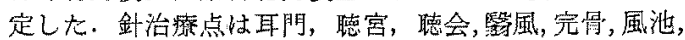
天柱，天容などの経穴加適宜数力所遙び，連日ないし 隔日に10回加

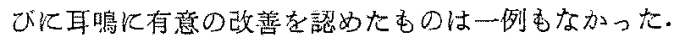

第N群は針麻酔効果である。症例が少なく特に言及で きないが，種々な局麻刘に過敏症をもつ例のてテローム 摘出街は針麻酔が有意嶬であった。

以上より電気針治㙩の效果と限界をまとめると，電気 針治療がよりよい效果在期待でる著效群恃直すしこ り，留こりとその随伴症状，急性炎症に伴う疼痛，顎関 節定, Hilger症侯群, 洀痕症候群, 難治性再発性アフタ などであった，次に一次的な効果るるいはある程橆の効

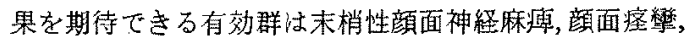
真性三叉神経痛, 癌性疼痛, メ二エ一儿病, 良性発作性頭 位胘侕症，椎筲脳底動脈循環不全症などであった。電気 針治療が等效であった珛は仮面うつ病や神経症に起因す る諸症状，あるいは心因性要秦の強い症例，感音性難㯖 と随伴する耳鳴，三叉神経幻覚痛，上顎全摘徭開口障害， 耳管開放症などであった。

結論篦気針治療は㑨病の随伴症状をとることによっ て患者の苦痛を和げる効果は期待でき，症例によっては 他の治療法では得られない硎的な效果が得られる。しか

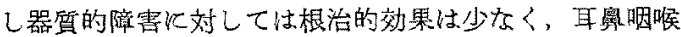
科疾患の根本的治療手段としてよりもむしる補助的治療 手段として澺㼁が古ると考える。

質問阙本途也(昭大)，货種疾患の方方心リ治療を行 う症例をどのようにして選んでいるか，応答 米山秀

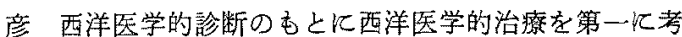
天，艺こに盲点がある場合に笔気治噔の有効生が期待 できる症例老谪応としている。筧問 調所廣之（関東 爫災）1）局麻剂使用の後頭神経ブロックと八リによる 方法との效果の比較について，2）演者自身でハリを刺 しているか，応答 米山秀彦 後頭神経ブロックの方 が確実性の点で戝れたいる。 今後針食師とチームを組 んでハリ治療を施行してみるつもりだ，ての結果返答が できると苧える。

(B 82-0954-00097)

\title{
5. 耳鼻咽喉科領域のハリ治療の效果と限界
}

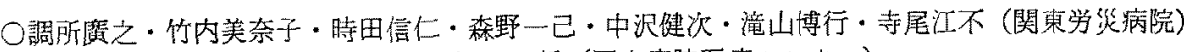 \\ 島山稳・江口哲（国立病院医痖せンタ一）
}

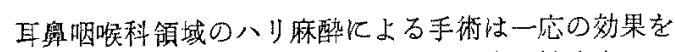

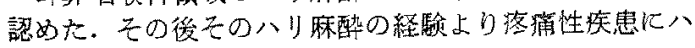

リ治揞を行ない，続いて難㙏，耳鳴，麻瘏性疾患，學疾 患と次第にその適応を拡けてきた。 
表 1 アンケートによるハリ治療の効果

\begin{tabular}{|c|c|c|c|c|c|c|c|c|}
\hline & & 難 聴 & 耳鳴 & 畺 炎 & 神経痛 & 顔面マヒ & その他 & 合 計 \\
\hline 1) & とても良くなった & $\begin{array}{c}13 \\
(9 \%)\end{array}$ & $\begin{array}{c}10 \\
(17 \%)\end{array}$ & $\stackrel{2}{2}$ & $\begin{array}{c}5 \\
(31 \%)\end{array}$ & $\begin{array}{c}19 \\
(61 \%)\end{array}$ & $\begin{array}{c}12 \\
(39 \%)\end{array}$ & 61 \\
\hline 2) & 少し良くなった & $\begin{array}{c}32 \\
(21 \%)\end{array}$ & $\begin{array}{c}16 \\
(28 \%)\end{array}$ & $\begin{array}{c}7 \\
(41 \%)\end{array}$ & $\begin{array}{c}4 \\
(25 \%)\end{array}$ & $\begin{array}{c}7 \\
(24 \%)\end{array}$ & $\begin{array}{c}13 \\
(42 \%)\end{array}$ & 29 \\
\hline 3) & 一時的ですった & $\begin{array}{c}23 \\
(15 \%)\end{array}$ & $\begin{array}{c}4 \\
(7 \%)\end{array}$ & $\begin{array}{c}3 \\
(18 \%)\end{array}$ & $\left(\begin{array}{c}2 \\
(13 \%)\end{array}\right.$ & $\begin{array}{c}2 \\
(6 \%)\end{array}$ & $\stackrel{2}{2}$ & 36 \\
\hline 4) & 効果がなかった & $\begin{array}{c}81 \\
(55 \%)\end{array}$ & $\begin{array}{c}28 \\
(48 \%)\end{array}$ & $\begin{array}{c}5 \\
(29 \%)\end{array}$ & $\begin{array}{c}5 \\
(31 \%)\end{array}$ & $\begin{array}{c}3 \\
(10 \%)\end{array}$ & $\begin{array}{c}4 \\
(13 \%)\end{array}$ & 126 \\
\hline
\end{tabular}

今回，耳鼻咽喉科領域の八リ治療の効果之限界以つ以 て, 昭和 45 年 53年の 6 年間関東学崖病院耳舅咽喉科八 リ治潦外来口経験を元儿報告与る。

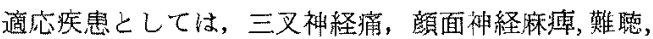

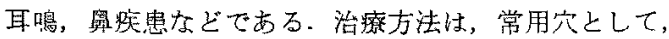

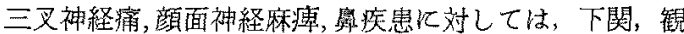
能，頓車，四白，迎香などの顔面局所の取穴，耳疾患に

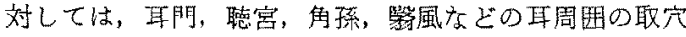
を主とし，他江合谷，曲池，外関，中渚，足三里，内庭 など手足の遠䏂部の取穴を行なった。八リ刺激としては

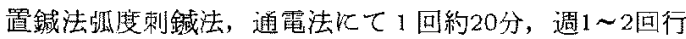
なった，使用した鍼は中国製ステンレス針を主とした。

それ発れの筷患の一括した效果について，それぞれの 著効例以ついてみると，三叉神経痛 130 例中35例(28\%) 顔面神経麻醉45例中 2 例 $(4 \%)$ ，難㯖27例中广し，耳鳴 105 例中 13 例 $(12 \%)$ ，㯖疾患30例中なしの結果加关られ た，八リ治療の効果判定には種々問題があり，自然治ゆ， 心理的な問題などを考魔した旋染なチェック基準を設け

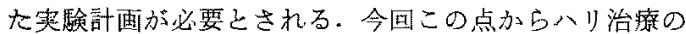
効果沉ついて著效例のみを選んでその効果を検討してみ 万と，疼痛性疾患飞此較的効果が良いと考光られた。

当科では西洋医学的㟝断の元化八リ治療を指示し，䙳

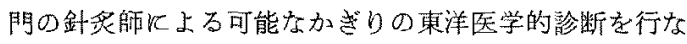

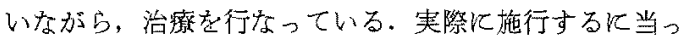
て络，治療洔閻，治療回数，方法，治療費請求の方法， 等比多くの問題がある.関学災病院では最近までハり 治療は耳舆咽喉科の管理下で行なってきた。しかし他科 の疾患比対しても八治療の希望屯多く，耳舅咽嶰科の

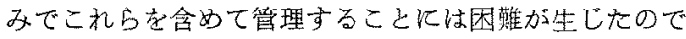
最近はり八ビリテェーション科の管理下で行るうように なった，治療回数は原則として週 2 回，治療時間は 1 回 $20 \sim 30$ 分である. 各症例の平均治療回数は13 回であ。 t.

八リ治病の効果至知る一方法として，今回過去のハリ 治㙩患者の一部爪，アンケートルよる追跡調査を実施し te.

アンケートの内容は，1）どえな症状，診断名でハリ

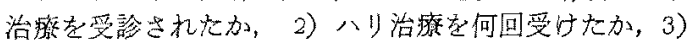
ハリ治痖洁本院がはじめてであるか，4）本院の八リ治 療はどこで知ったか，5）八リ治療受受けて效果があっ たか，6）現在の症状はどうであるか，7）現在どのよ
ろ存治療を受けているか，8）八リ治潦を受けた感想， 意見について，などからなっている。このアンケートを 関東学災病院耳䁷咽喉科八リ外来索受診したもの亡，昭 和大学耳啇咽喉科ハリ外来を受竞したものに対して実施 Lt.

アンケート総数は関東学災病院 272 例，昭和大学 400 例であり，この内解答数は前者は 111 例（回取率40\%)， 後者は 209 例 (回収率 $52 \%$ )で，両者で 320 の解答を文 た，平均の治療回数は関東学災は13回であったが，昭和 大学江 53 回でか子り差があった。各疾患别の症例数は 1) 難㯖 147 例，2）耳鳴 70 例，3）舆炎 17 例，三叉神経 痛17例，顔面神経麻序34例，之の他35例であった。

八リ治療峙本院がはしめてであるかという閔に対し て，関東労災では 99 例 $(89 \%)$ が，昭和大学では 179 例 (89\%) 加“怯い”之答党ている。本院のハリ治療活と こで知ったかという閔に対しては関東学垈では雑誌16例 $(14 \%)$ ，人の紹介 17 列 $(15 \%)$ ，受㟝して始的て知った70 例 $(64 \%)$ ，艺の他 8 例 $(7 \%)$ でり，昭和大学では雜誌 12 例 $(6 \%)$, 人の紹介 74 例 $(37 \%)$, 受診して始好て知った 73例 $(36 \%)$ ，その他 43 例(21\%)であった.

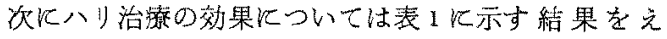
た. 現在の症状についての問では，関東学災ではよくな った 43 例 $(41 \%)$ 变化なし 52 例(50\%)悪くなった 10 例 $(9 \%)$, 昭和大学ではくなった 50 例 $(26 \%)$ 变化なし 113 例 $(59 \%)$, 悪くなった29例 (15\%)であった. 現在ど

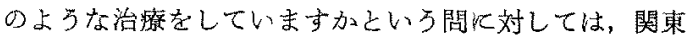
学災ては，していない87列(79\%)している23列(21\%)， 昭和大学ではしていない148例 (76\%)，している46例 (24\%)の結果をえた。これら治療をしている例で优半数 は柬洋医学的治潦を行なっていた。

八リ治療を吅けた感想としては，まっと続けたいとい 了例が多く，洔間的余裕がなく中止した例が多かった。 その他, 保隃投でしほしい，八りが非常に痛かった， 気分が良くなった，安脏できるよらになった，局こりが とれた，櫬痛がとれたなどの主訴とは别の症状に效果が 良加ったいう症例加多加つた。

質問岡本途也（晒和大）八》治療を指示する医師 側の問題点は? 応答 調所度之 ハリ治療遮応の選択

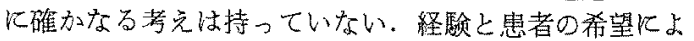
って决めているこ之が多い。

(B 82-0955-91999) 